as news", Mr. Watson Davis said that the reporting and interpretation of science failed of its purpose if it did not bring about an appreciation and utilization of scientific method in everyday life. This he believed was best achieved by giving the mass of the people, through accurate and interesting accounts of science's successes and failures, some understanding of the essence of science which would lead them to apply it more widely to our everyday life, our human relationships, business and government. Many of the ideals we most cherished such as liberty, opportunity, the pursuit of happiness, freedom, democracy, were achieved by the utilization of scientific method, and the mistakes of democracy were best corrected by science.

THIs belief, that the only way of making democracy safe for itself was to make it more intelligent and accordingly more scientific, inspired the founders of Science Service, E. W. Scripps and Dr. W. E. Ritter. Many opportunities of such service were as yet only imperfectly used. For example, the scientific aspects of the recent disastrous floods had received little publicity, and the possibilities of books and magazines as media have yet to be fully developed. In this work quality is all important, and the first objective is the exact opposite of propaganda. It is to present facts in a readable and interesting form, on which the reader could base his own opinions on a subject of politics, sociology or his duty to his fellows. In recalling this statement of the founders of Science Service as to its objectives, Mr. Watson Davis emphasized that not even science must be allowed to become a dictator. It should set the example for straight thinking, confident that the process of democracy, guided by scientific method and reason, would give effective results.

\section{Development of the Oil Engine}

The millions of compression-ignition oil engines in use to-day have all sprung from the initial work of Herbert Akroyd Stuart (1864-1927) and Rudolph Diesel (1858-1913), whose outstanding patents were taken out in 1890 and 1892 respectively. Vast sums of money have been spent by Governments, firms, institutions and individuals in experiments with oil engines, but just as the first successful Diesel engine was the outcome of the work during 1893-97 of the Maschinenfabrik-Augsburg-Nurnberg, so the success of the engine invented by Akroyd Stuart-known as the "Hornsby-Akroyd" engine-was due to the pioneering work of Messrs. Hornsby and Sons, Ltd., of Grantham, now Ruston and Hornsby, Ltd., of Lincoln. Having offered his patents to various gas engine makers, Stuart approached Messrs. Hornsby, and in $\mathbf{1 8 9 1}$ they agreed to take up the development of Stuart's engine on a royalty basis. The necessary experimental work was entrusted to Mr. J. W. Young, who in a paper entitled "Notes on the Practical Development of the Oil Engine" read to the Newcomen Society on March 17, gave an interesting account of the difficulties which had to be overcome before the "Hornsby-Akroyd" engine could be placed on the market.
STUaRT's principal patents were No. 7146 of May 1890 and No. 15994 of October 1890 and these covered compression ignition and airless injection, and also the use of a vaporizer. The most difficult problem was that of combustion, and many forms of vaporizers were tried. The construction of oil engines, too, demanded a higher standard of workmanship than the steam engines, and cylinders, pistons and piston-rings were all the subject of many experiments. Both fuel oil and lubricating oil raised many problems, especially as the oil refiners of that time, had not succeeded in removing certain resinous bodies from the oil. In connexion with this, Mr. Young was sent to Russia, where Messrs. Nobel Brotbers co-operated in introducing a uniform standard of distillation. As regards the development of the "Hornsby-Akroyd" engine Stuart took no part after 1891. He migrated to Western Australia about 1900 and died there on February 19, 1927. The so-called semi-Diesel engine is properly an Akroyd-Stuart engine, and nearly all makers of Diesel engines now use his method of airless injection, and not air-blast injection as introduced by Diesel.

\section{Chair in Biblical Archæology: an Appeal}

AN appeal for funds to endow a chair in biblical archæology in connexion with the Institute of Archæology of the University of London, has been issued over the signatures of the Archbishop of Canterbury, Sir Frederic Kenyon, Sir George Hill and Sir Charles Peers, should meet with a ready and liberal response, especially as the generous gift by Sir Charles Marston of $£ 1,000$ has already reduced substantially the amount which it is considered necessary to provide. Palestine demands of the field worker a widely extended and detailed knowledge of the general cultural and historical background, owing to its geographical position and its political, economic, and cultural relations with contemporary peoples. The institution of a chair in biblical archæology, by making provision for that preliminary training in acquisition and manipulation of the historical and cultural facts of the Ancient World, should go far towards conserving the time and energy of senior members of an expedition, which must be devoted to the training and supervision of the younger workers in the field. Not only does the installation of Sir Flinders Petrie's Palestinian collections at the Institute of Archæology make this an opportune moment to inaugurate such a chair, but also the results which have been achieved by recent excavation in Palestine, as for example at Lachish, Jericho and Gaza, as well as indications of the bearing of Palestinian material on the excavations now being carried out in Syria, all point in the direction of the imminent possibility of important additions to knowledge. This should be an additional stimulus to the British public, who have always looked kindly upon research in Palestine. Contributions may be sent to Mr. E. S. M. Perowne, 7 Great James Street, Bedford Row, W.C.1, or direct to the Westminster Bank, Marylebone Branch, 1 Stratford Place, Oxford Street, W.1, marked "Institute of Archæology". 